\section{Optical Sensing of Turfgrass Chlorophyll Content and Tissue Nitrogen}

\author{
G.E. Bell ${ }^{1}$ \\ Department of Horticulture and Landscape Architecture, Oklahoma State \\ University, Stillwater, OK 74078
}

B.M. Howell

Oklahoma State University, Tulsa, OK 74106

G.V. Johnson and W.R. Raun

Department of Plant and Soil Sciences, Oklahoma State University, Stillwater, OK 74078

\section{J.B. Solie and M.L. Stone \\ Department Biosystems and Agricultural Engineering, Oklahoma State University, Stillwater, OK 74078}

Additional index words. plant nutrition, plant pigments, remote sensing, turfgrass, variable rate technology

\begin{abstract}
Differences in soil microenvironment affect the availability of $\mathbf{N}$ in small areas of large turfgrass stands. Optical sensing may provide a method for assessing plant $\mathbf{N}$ needs among these small areas and could help improve turfgrass uniformity. The purpose of this study was to determine if optical sensing was useful for measuring turfgrass responses stimulated by $\mathrm{N}$ fertilization. Areas of ' $\mathrm{U} 3$ ' bermudagrass [Cynodon dactylon $(\mathrm{L}$.) Pers.], 'Midfield' bermudagrass [C. dactylon (L.) Pers. x C. transvaalensis Burtt-Davy], and 'SR1020' creeping bentgrass (Agrostis palustris Huds.) were divided into randomized complete blocks and fertilized with different $\mathbf{N}$ rates. A spectrometer was used to measure energy reflected from the turfgrass within the experimental units at 350 to1100 nm wavelengths. This spectral information was used to calculate normalized difference vegetation index (NDVI) and green normalized difference vegetation index (GNDVI). These spectral indices were regressed with tissue $\mathbf{N}$ and chlorophyll content determined from turfgrass clippings collected immediately following optical sensing. The coefficients of determination for NDVI and GNDVI regressed with tissue $\mathrm{N}$ averaged $r^{2}=0.76$ and $r^{2}=0.81$, respectively. The coefficients of determination for NDVI and GNDVI regressed with chlorophyll averaged $r^{2}=0.70$ and $r^{2}=0.75$, respectively. Optical sensing was equally effective for estimating turfgrass responses to $\mathbf{N}$ fertilization as more commonly used evaluations such as shoot growth rate (SGR regressed with tissue $N ; r^{2}=0.81$ ) and visual color evaluation (color regressed with chlorophyll; $r^{2}=0.64$ ).
\end{abstract}

Turfgrass and other plants obtain nutrients primarily from the soil in which they grow. Research indicates that the nutrient retention of soils can vary appreciably in areas less than $1 \mathrm{~m}$ apart (Raun et al., 1998). Soil or tissue testing is too expensive and requires too much labor for measuring nutritional needs in areas smaller than several hundred square meters. Nitrogen, in particular is highly variable in both time and space and soil tests are rarely effective for determining turfgrass $\mathrm{N}$ need. Optical sensing, a method that measures energy reflected from turfgrass leaves to determine plant status, shows promise for measuring nitrogen needs in submeter sections of large turfgrass areas. Combined with variable rate spray technology, optical sensing could be used

Received for publication 7 Feb. 2003. Accepted for publication 2 Sept. 2003. Approved for publication by the director of the Oklahoma Agricultural Experiment Station. Funding provided by Deere, Inc., Moline, Ill., grant number AG-97-RS-120 and The Oklahoma Agricultural Experiment Station, project number OKLO 2392.

${ }^{1}$ Corresponding author; e-mail bgregor@okstate.edu. fective for measuring grain yield in wheat (Triticum aestivum L.) (Serrano et al., 2000) and corn (Zea mays L.) (Shanahan et al., 2001). Normalized difference vegetation indices provided accurate determination of tissue $\mathrm{N}$ in wheat (Stone et al., 1996), cotton (Gossypium hirsutum L.) (Tarpley et al., 2000), and corn (Bausch and Duke, 1996). Stone et al. (1996) demonstrated that fertilizer applications based on optical sensing evaluation were effective for topdressing wheat. Similar sensing instruments could be incorporated with variable-rate sprayers for applying nutrients to small units of large turfgrass areas based on plant need. Shoot growth rate and visual evaluation are commonly used to determine when turfgrass requires $\mathrm{N}$ fertilization. Visual evaluation is acceptable for this purpose but may not be as accurate as quantitative measures such as tissue reflectance (Rodriguez and Miller, 2000) and canopy reflectance. In studies conducted by Trenholm et al. (1999) and Bell et al. (2002b), researchers found that reflectance from turfgrass was closely related to turfgrass quality or components of quality such as color. Research using quantitative measures to compare the accuracy of shoot growth rate or visual evaluation with the accuracy of canopy reflectance for measures of turfgrass $\mathrm{N}$ status provides useful information for the improvement of variable rate technology. The purpose of this study was to determine if optical sensing was useful for measuring turfgrass responses stimulated by $\mathrm{N}$ fertilization.

\section{Materials And Methods}

Research was initiated in May 1997 on mature stands of 'Midfield' hybrid bermudagrass, 'U3' common bermudagrass, and 'SR1020' creeping bentgrass at three sites. Each of the sites varied in soil composition as well as turfgrass species and/or cultivar. The U3 bermudagrass site was a Norge silt loam (finesilty, mixed, active, thermic, Udic Paleustolls) and the Midlawn bermudagrass site was Easpur loam (fine-loamy, mixed, superactive, thermic Fluventic Haplustolls). The SR1020 creeping bentgrass site was sand (United States Golf Association specifications) amended with $10 \%$ rice hulls (v/v) during construction in 1994. Both bermudagrass sites were mowed at 13 $\mathrm{mm}$ and the creeping bentgrass site was mowed at $4 \mathrm{~mm}$. Each site received six $\mathrm{N}$ treatments replicated four times to obtain data over a wide range of available N. Bermudagrass sites received treatments of $24,49,73,98,195$, and 293 $\mathrm{kg} \mathrm{N} / \mathrm{ha}$. The creeping bentgrass site received treatments of $6,18,30,42,54$, and $67 \mathrm{~kg} \mathrm{~N} / \mathrm{ha}$. Plots of $91 \times 91 \mathrm{~cm}$ were replicated four times in randomized complete blocks at all sites and ammonium nitrate (34-0-0) was used as the $\mathrm{N}$ source. Optical sensing was performed immediately before clippings were collected at random intervals during the growing season. Optical measurements and harvests were made on 'U3' and 'Midfield' on 16 July, 24 Aug, 2 Sept, and 9 Sept and on 'SR1020' on 4 and 18 June 1998. Clippings were collected using a reel mower with a standard collection basket and were used to determine shoot growth 
rate, tissue chlorophyll content, and tissue $\mathrm{N}$ concentration.

Tissue analysis. Following collection, grass clippings were dried at $49^{\circ} \mathrm{C}$ for $24 \mathrm{~h}$. After drying, the clippings were weighed, ground in a cyclone mill, and divided into samples for chlorophyll and nitrogen extraction. Dry clipping weight and collection area were used to compute shoot growth rate $\left(\mathrm{kg} \cdot \mathrm{ha}^{-1} \cdot \mathrm{d}^{-1}\right)$ for comparison with NDVI and other variables.

Chlorophyll analysis followed the procedures of Johnson (1974). Chlorophyll was extracted in methanol $(50 \mathrm{~mL}$ methanol per 50 $\mathrm{mg}$ tissue) for $20 \mathrm{~h}$. After gently shaking the mixture, the samples were allowed to settle for an additional $2 \mathrm{~h}$. Absorbance was measured using a spectrometer (Spectronic 401; Milton Roy, Ivyland, Pa.) set at $660 \mathrm{~nm}$. Sample absorbance was converted to milligrams of chlorophyll per gram ( $1 \mathrm{~L}$ methanol $=1 \mathrm{~g}$ tissue $)$ using a concentration curve developed by plotting the calculated chlorophyll concentrations of serial dilutions of a concentrated sample solution against absorbance at 650 and 665 $\mathrm{nm}$ wavelengths. Chlorophyll concentration for the diluted samples was calculated using the formula total chlorophyll $\left(\mathrm{g} \cdot \mathrm{L}^{-1}\right)=0.0256$ absorbance $_{650}+0.004$ absorbance $_{665}$, which applies when the spectrometer light path is $1 \mathrm{~cm}$. Total $\mathrm{N}$ was determined using a dry combustion analyzer (NA 1500; Carlo-Erba, Milano, Italy).

Optical sensing. The optical sensing instrument was a S2000 spectroradiometer (Ocean Optics, Dunedin, Fla.) connected to a sheet metal hood with a naked fiberoptic cable that was used for energy collection. The hood measured $61 \mathrm{~cm}$ tall $\times 61 \mathrm{~cm}$ wide and tapered from $46 \mathrm{~cm}$ long at the base to $15 \mathrm{~cm}$ long at the top. The interior of the hood was darkened with flat black paint and artificial lighting was added. Radiance was supplied by two 120-W incandescent flood lamps and two infrared heat lamps. The fiber optic collector was mounted above the artificial lights, $61 \mathrm{~cm}$ from the turf, so that reflected energy from a round turfgrass area $41 \mathrm{~cm}$ in diameter was measured. The hood was placed on the turf providing a seal that prevented ambient solar energy from influencing the detector. Three measurements were made from random locations on each turfgrass plot and a mean was calculated for analysis. Red (R; $670 \pm 6 \mathrm{~nm}$ wavelength) and near infrared (NIR;780 $\pm 6 \mathrm{~nm}$ wavelength) reflection were divided by white plate measurements at the same wavelengths and the resulting reflectance was used to calculate normalized difference vegetation indices $[\mathrm{NDVI}=(\mathrm{NIR}-\mathrm{R}) /(\mathrm{NIR}+\mathrm{R})]$ for each plot. A second spectral indicator, green $(G)$ normalized difference vegetation index $(\mathrm{G}=550 \pm 6$ $\mathrm{nm}$ ), was also calculated and used for analysis $[$ GNDVI $=(\mathrm{NIR}-\mathrm{G}) /(\mathrm{NIR}+\mathrm{G})]$.

In addition, three evaluators ( 2 experienced turfgrass evaluators and 1 novice) rated each plot for visual turfgrass color on a scale of 1 to 9 ( 1 = brown; 5 = yellow; 9 = dark green) before optical sensing and clipping collections.

Data presentation and analysis. Relationships between NDVI, or GNDVI and measured variables were evaluated using curvilinear regression and correlation. Responses were considered significant when $P<0.001$. The species and cultivars tested represent the same experiment conducted in three locations. Consequently, regression and correlation were calculated within cultivars. Relationships were determined from data collected and compared among experimental units (plots) to take advantage of the variability both among and within $\mathrm{N}$ rate treatments. Visual color ratings presented are the average of three individuals. These visual averages were deemed an accurate, unbiased measure of turfgrass color and were a fair comparison with the average of three optically sensed subsamples collected from each experimental unit.

This study used increasing $\mathrm{N}$ fertilizer treatments to stimulate turfgrass responses normally associated with $\mathrm{N}$ fertility. These responses (tissue $\mathrm{N}$ and chlorophyll content) were then regressed with spectral indices. Those results were compared with regressions of factors (SGR and visual color) commonly used to determine turfgrass $\mathrm{N}$ status in the field that were also regressed with spectral indices. It was beyond the scope of the study to determine models that accurately define the relationships between $\mathrm{N}$ application rates and turfgrass responses such as tissue $\mathrm{N}$ and tissue chlorophyll content. However, it was necessary to determine if the $\mathrm{N}$ rates applied in the study caused tissue $\mathrm{N}$ and chlorophyll to differ among treatments. Standard deviations were computed within treatments, sites, and rating dates, to determine the variation among plots treated alike.

\section{Results and Discussion}

Second order polynomial regressions were used to describe all relationships discussed. Linear relationships were significant in most cases but second order relationships always had stronger correlation. Third and fourth order polynomials provided slightly stronger relationships in most cases but did not follow the sigmoid pattern normally associated with plant responses. All second order polynomial relationships discussed were highly significant $(P<0.001)$.

Second-order polynomial regressions indicated that relationships between the nitrogen application rates and turfgrass responses during the study followed expected trends. Tissue $\mathrm{N}$ and chlorophyll content significantly increased with increasing $\mathrm{N}$ rate at all sites on all rating dates (Table 1). The average standard deviation in tissue $\mathrm{N}$ among plots treated alike was $0.21\left(\right.$ mean $\left.=3.93 \mathrm{mg} \cdot \mathrm{g}^{-1}\right)$ and for chlorophyll content was $0.44\left(\right.$ mean $\left.=6.55 \mathrm{mg} \cdot \mathrm{g}^{-1}\right)$ indicating that all plots varied both within and among $\mathrm{N}$ rates. Consequently, the $\mathrm{N}$ rates applied successfully caused the plot variation necessary to test turfgrass responses against spectral indices on an individual plot basis. Coefficients of determination for within plot comparisons were either very strong $\left(r^{2}=0.90\right.$ $-1.00)$, strong $\left(r^{2}=0.70-0.89\right)$, or moderate $\left(r^{2}=0.50-0.69\right)$ for $\mathrm{N}$ rate regressed with tissue $\mathrm{N}$ or chlorophyll depending on rating date (Table 1).

Turfgrass managers often monitor SGR to determine the need for $\mathrm{N}$ fertilization. For NDVI and/or GNDVI to be considered successful indicators of turfgrass $\mathrm{N}$ status, these spectral indices should assess turfgrass $\mathrm{N}$ status with accuracy similar to, or superior to, SGR. Second order polynomial regressions of SGR with tissue $\mathrm{N}$ computed within plots indicated highly significant $(P<0.001)$, positive relationships on all rating dates. The strength of these relationships ranged from $r^{2}=0.61$ to $r^{2}=0.97$ and averaged $r^{2}=0.81$ for the 10 combinations of rating date and site (Table 1). The SGR with tissue N relationship was slightly stronger than NDVI with tissue $\mathrm{N}\left(r^{2}\right.$ $=0.76)$ and equal to GNDVI with tissue $\mathrm{N}\left(r^{2}\right.$ $=0.81$ ) when the results were averaged over all sites. The SGR with tissue N relationship was stronger than GNDVI with tissue $\mathrm{N}$ at the

Table 1. Coefficients of determination for second-order polynomial regressions ${ }^{\mathrm{z}}$ computed within plots between N application rates, shoot growth rate (SGR), visual turfgrass color, normalized difference vegetation indices (NDVI), green normalized difference vegetation indices (GNDVI), and turfgrass responses, including tissue chlorophyll content and tissue N.

\begin{tabular}{|c|c|c|c|c|c|c|c|c|c|c|c|c|}
\hline & & \multicolumn{11}{|c|}{$r^{2} \times 100$} \\
\hline & & \multicolumn{8}{|c|}{ Bermudagrass } & \multirow{2}{*}{\multicolumn{2}{|c|}{$\begin{array}{c}\text { Bentgrass } \\
\text { SR1020 }\end{array}$}} & \multirow[b]{3}{*}{ Mean' } \\
\hline \multicolumn{2}{|c|}{ Variable } & \multicolumn{4}{|c|}{ U3 } & \multicolumn{4}{|c|}{ Midfield } & & & \\
\hline Independent & Dependent & 16 July & 24 Aug. & 2 Sept. & 9 Sept. & 16 July & $8 / 24$ & 2 Sept. & 9 Sept. & 4 June & 18 June & \\
\hline $\mathrm{N}$ rate & tissue $\mathrm{N}$ & 98 & 94 & 89 & 94 & 94 & 99 & 85 & 84 & 77 & 94 & 90 \\
\hline $\mathrm{N}$ rate & chlorophyll & 80 & 72 & 71 & 72 & 90 & 94 & 58 & 47 & 86 & 91 & 74 \\
\hline SGR & tissue $\mathrm{N}$ & 90 & 91 & 76 & 86 & 90 & 97 & 77 & 68 & 61 & 83 & 81 \\
\hline NDVI & tissue $\mathrm{N}$ & 76 & 70 & 68 & 80 & 85 & 97 & 66 & 65 & 78 & 96 & 76 \\
\hline GNDVI & tissue $\mathrm{N}$ & 91 & 83 & 67 & 72 & 92 & 98 & 72 & 75 & 79 & 96 & 81 \\
\hline color & chlorophyll & 63 & 86 & 62 & 46 & 85 & 84 & 49 & 44 & 63 & 82 & 64 \\
\hline NDVI & chlorophyll & 90 & 82 & 56 & 53 & 89 & 92 & 56 & 48 & 76 & 91 & 70 \\
\hline GNDVI & chlorophyll & 91 & 82 & 69 & 51 & 88 & 95 & 70 & 54 & 80 & 92 & 75 \\
\hline
\end{tabular}

${ }^{\mathrm{z}}$ All relationships $\left(\mathrm{y}=\mathrm{a}+\mathrm{bx}+\mathrm{cx}^{2}\right)$ were highly significant $(P<0.001)$.

${ }^{y}$ Mean correlation over all sites and dates. 
U3 site, about equal at the Midfield site, and weaker at the SR1020 site. The differences, however, were small and probably meaningless. The strength of the GNDVI with tissue N relationship exceeded the strength of the NDVI with tissue $\mathrm{N}$ relationship on all dates at the Midfield bermudagrass site, but the indices were about equal for estimating $\mathrm{N}$ status in U3 bermudagrass. The NDVI was about equal to the GNDVI for estimating $\mathrm{N}$ status at the U3 bermudagrass and the SR1020 creeping bentgrass site as well.

Turfgrass managers also determine turfgrass nitrogen need through visual turfgrass color evaluation. A close relationship between plant color and chlorophyll content is generally assumed in plant science and it is well known that $\mathrm{N}$ applications enhance turfgrass color in most instances. Relationships between visual color and tissue chlorophyll content were compared with relationships between spectral indices and tissue chlorophyll content to determine if the spectral indices could estimate chlorophyll content as accurately as visual color could estimate chlorophyll content.

Second-order polynomial regressions of visual color (averaged over three human evaluators) with chlorophyll content over 10 combinations of rating date and site had coefficients of determination that ranged from $r^{2}=0.44$ to $r^{2}=0.86$ and averaged $r^{2}=0.64$ (Table 1). Both spectral indices demonstrated stronger relationships with chlorophyll content than did visual color. Relationships between NDVI and chlorophyll content had coefficients of determination that ranged from $r^{2}=0.53$ to $r^{2}=0.92$ and averaged $r^{2}=0.70$. Relationships between GNDVI and chlorophyll ranged from $r^{2}=0.51$ to $r^{2}=0.92$ and averaged $r^{2}=0.75$. The results suggested that NDVI was a better estimator of chlorophyll content than visual color evaluation and that GNDVI was a better estimator than NDVI. Again, however, the differences between NDVI and GNDVI were slight and inconsistent among rating dates and were probably meaningless.

The relationships of spectral indices with SGR support the work of Daughtry et al. (1992) who found NDVI to be a good measure for plant biomass in wheat and that of Serrano et al. (2000) and Lawrence et al. (2000) who studied biomass in corn, soybeans [Glycine max (L.) Merr.], and pearl millet [Pennisetum glaucum (L.) R. Br.]. An important aspect of optical sensing is the potential for combination with variable rate $\mathrm{N}$ fertilization. The combination of on-the-go sensing and variable application or optical sensing and post application could be used to fertilize areas smaller than one square meter with variable application rates based on plant status. These results supported those of Stone et al. (1996) who found that a variation of NDVI effectively measured $\mathrm{N}$ status in wheat and those of Bell et al. (2002a) who found strong correlations between NDVI and N fertility in creeping bentgrass. Based on the findings of Raun et al. (1998), nutrient availability and uptake can vary significantly on a submeter scale in bermudagrass (Cynodon dactylon L.) forage. These studies combine to indicate a need for submeter variable fertilization and the potential use of optical sensing combined with variable rate fertilization.

The results of this study indicated that both NDVI and GNDVI were equally effective for estimating turfgrass $\mathrm{N}$ status as SGR and that these indices were equally effective for estimating turfgrass chlorophyll content as visual color evaluation. The GNDVI was the better overall spectral index for estimating turfgrass status but the difference was small and possibly meaningless. These two spectral indices may be useful for gathering objective, quantitative, and rapid field estimates of turfgrass $\mathrm{N}$ status and chlorophyll status.

\section{Literature Cited}

Bausch, W.C. and H.R. Duke. 1996. Remote sensing of plant nitrogen status in corn. Trans. ASAE 39: 1869-1875.

Bell, G.E., D.L. Martin, M.L. Stone, J.B. Solie, and G.V. Johnson. 2002a. Turf area mapping using vehicle-mounted optical sensors. Crop Sci. 42: 648-651.

Bell, G.E., D.L. Martin, S.G. Wiese, D.D. Dobson, M.W. Smith, M.L. Stone, and J.B. Solie. 2002b. Vehicle-mounted optical sensing: An objective means for evaluation of turf quality. Crop Sci. 42:197-201.

Datt, B. 1998. Remote sensing of chlorophyll a, chlorophyll $\mathrm{b}$, chlorophyll $\mathrm{a}+\mathrm{b}$, and total carotenoid content in eucalyptus leaves. Remote Sens. Environ. 66:111-121.

Daughtry, C.S., K.P. Gallo, S.N. Goward, S.D. Prince, and W.P. Kustas. 1992. Spectral estimates of absorbed radiation and phytomass production in corn and soybean canopies. Remote Sens. Environ. 39:141-152.

Gamon, J.A., C.B. Field, W. Bilger, O. Björkman, A.L. Fredeen, and J. Peñuelas. 1990. Remote sensing of the xanthophyll cycle and chlorophyll fluorescence in sunflower leaves and canopies. Oecologia 85:1-7.

Gitelson, A.A., Y.J. Kaufman, and M.N. Merzlyak. 1996. Use of a green channel in remote sensing of global vegetation from EOS-MODIS. Remote Sens. Environ. 58:289-298.

Johnson, G.V. 1974. Simple procedure for quantitative analysis of turfgrass color. Agron. J. 66: 457-459.

Lawrence, P.R., B. Gérard, C. Moreau, F. Lhériteau, and A. Guerkert. 2000. Design and testing of a global positioning system-based radiometer for precision mapping of pearl millet total dry matter in the Sahel. Agron. J. 92:1086-1095.

Lichtenthaler, H.K., A. Gitelson., and M. Lang. 1996. Non-destructive determination of chlorophyll content of leaves of a green and an aurea mutant of tobacco by reflectance measurements. J. Plant Physiol. 148:483-493.

Raun, W.R., J.B. Solie, G.V. Johnson, M.L. Stone, R.W. Whitney, H.L. Lees, H. Sembiring, and S.B. Phillips. 1998. Microvariability in soil test, plant nutrient, and yield parameters in bermudagrass. Soil Sci. Soc. Amer. J. 62:683-689.

Rodriguez, I.R., and G.L. Miller. 2000. Using near infrared reflectance spectroscopy to schedule nitrogen applications on dwarf-type bermudagrasses. Agron. J. 92:423-427.

Rouse, J.W., R.H. Haas, J.A. Schell, and D.W. Deering. 1973. Monitoring vegetation systems in the Great Plains with ERTS, p. 309-317. In: 3rd ERTS Symp. NASA AP-351. vol. 1. NASA, Wash., D.C.

Serrano, L., I. Filella, and J. Peñuelas. 2000. Remote sensing of biomass and yield of winter wheat under different nitrogen supplies. Crop Sci. 40:723-731.

Shanahan, J.F., J.S. Schepers, D.D. Francis, G.E. Varvel,W.W.Wilhelm, J.M. Tringe, M.R. Schlemmer, and D.J. Major. 2001. Use of remote-sensing imagery to estimate corn grain yield. Agron. J. 93:583-589.

Stone, M.L., J.B. Solie, W.R. Raun, R.W. Whitney, S.L. Taylor, and J.D. Ringer. 1996. Use of spectral radiance for correcting in-seasonfertilizernitrogen dificiencies in winter wheat. Trans. ASAE 39(5): 1623-1631.

Tarpley, L., K. Reddy, and G.J. Sassenrath-Cole. 2000 Reflectance indices with precision and accuracy in predicting cotton leaf nitrogen concentration. Crop Sci. 40:1814-1819.

Thomas, J.R. and G.F.Oerther. 1972. Estimating nitrogen content of sweet pepper leaves by reflectance measurements. Agron. J. 64:11-13.

Trenholm,L.E. R.N. Carrow, and R.R. Duncan. 1999 Relationship of multispectral radiometry data to qualitative data in turfgrass research. Crop Sci. 39:763-769. 